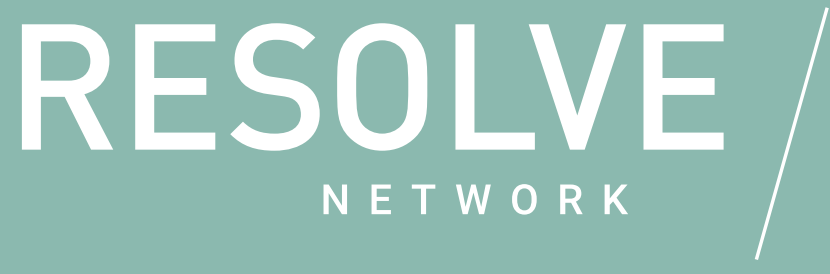

https://doi.org/ 10,37805/pn2021.4.wb

\title{
РЕИНТЕГРАЦИЈА КАКО ИМПЕРАТИВ ДЕЦАТА ПОВРАТНИЦИ НА ЗАПАДЕН БАЛКАН
}

\author{
АДРИАН ШТУНИ
}

\section{СЕРИЈА ЗА ЗАПАДЕН БАЛКАН}

\section{"Новите истражувања и програми за повратниците од Cuрија} и од Ирак се само почеток во решавањето на предизвикот на малолетни повратници.

\section{БРЗИ ФАКТИ}

$\rightarrow$ Cè на сѐ, како што се проценува, околу 500 странски борци и членови на нивните семејства од Западен Балкан и натаму се наоѓаат во Сирија и во Ирак.

$\rightarrow$ Мажи борци, наводно, претставуваат околу една третина од лицата од Западен Балкан што и натаму се наоѓаат во Сирија. Децата претставуваат околу две третини, а жените мал број.

$\rightarrow$ Сегашната демографија на млади лица странски државјани поврзани со сирискиот конфликт бара проактивно дејствување, посебно размислување за возраста и полот и соодветни приспособувања на одговорите на политиките, во очекување на нивна репатријација.

\section{Контекст}

Од 2012 година 1.070 државјани на земјите од Западен Балкан заминале да живеат и да се борат на териториите контролирани од терористичките организации во Сирија и во Ирак. Од нив, во времето на заминување 200 лица биле малолетни. Со текот на годините, уште голем број деца биле родени во арената на сирискиот и на ирачкиот конфликт од родители државјани на земји од Западен Балкан. Од крајот на 2019 година околу 485 лица се вратиле дома, со што Западен Балкан станал регион со најголема концентрација на повратници од Сирија и од Ирак во Европа. ${ }^{1}$ Уште неколку стотици лица, главно малолетници, остануваат во стапица во несигурните услови во

ЗАБЕЛЕШКА: За повеќе податоци и детална процена на моментната состојба на контингентот странски борци и нивни членови на семејства од Западен Балкан, види: Adrian Shtuni, "Western Balkans Foreign Fighters and Homegrown Jihadis: Trends and Implications, Combating Terrorism," СтC Sentinel 12, no. 7 (13 август 2019 год.):1824, https://ctc. usma.edu/western-balkans-foreign-fightershomegrown-jihadis-t rends-implications/. 
Сирија, со неизвесни изгледи за враќање. ${ }^{2}$ Голем број земји се справуваат со ситуацијата во која не знаат што да прават со државјаните што отишле да живеат и да се борат во таканаречената Исламска држава (ИД) „калифат.“ Меѓутоа, искуството и разбирањето на она што го олеснува ефикасното ангажирање кај повратниците од Сирија, особено кај децата повратници од Сирија, е во раните фази. Оваа Студија за политиките дава препораки за начините за пристап до рехабилитацијата и реинтеграцијата (РP) на деца повратници на Западен Балкан, комбинирајќи ги новите добри практики со водечките принципи на конвенциите, договорите и на протоколите фокусирани на правата на децата.

\section{Кампови за интернирани лица, првична репатријација и постојани предизвици}

По колапсот на физичкиот „калифат“ на ИД, десетици илјади борци што се предале и членови на нивните семејства се држани во пренатрупани курдски притворски објекти и кампови за интерно раселени лица (ИРл). Во кампот Ал-Хол, најголем камп во кој се сместени членови на семејствата на борци на ИД, во август 2019 година биле сместени 68.823 лица ${ }^{3}$ - првично беше планирано во кампот да бидат сместени околу седумпати помалку луѓе. ${ }^{4}$ Во неодамнешен извештај од Советот на Обединетите нации за човекови права условите во Ал-Хол се опишани како „бедни и нехумани. “5 Од вкупната популација на Ал-Хол, околу 7.000 лица се малолетни странски државјани, додека околу 3.000 се жени странски државјани од околу 50 земји ${ }^{6}$ - вклучително и повеќе стотини од Западен Балкан.

Сѐ на сѐ, како што се проценува, околу 500 странски борци и членови на нивните семејства од Западен Балкан и натаму се наоѓаат во Сирија и во Ирак. Една третина од овој контингент од Западен Балкан, наводно, се мажи борци, додека две третини се деца и мал број се жени. Голем број од овие борци и членови на семејствата сакаат да се вратат во своите татковини.

Досега повеќето влади се колебливи да ги репатрираат своите државјани поради технички и законски тешкотии, политички прашања и безбедносни прашања. ${ }^{7}$ Еропските држави, како што се Франција, Германија, Холандија, Норвешка и Белгија се определиле да репатрираат - речиси ексклузивно - само мал број деца на нивни државјани што се приклучиле на ИД, кои останале сирачиња. Косово е една од неколкуте земји во Европа што досега прифатиле групна репатријација на 110 државјани, од кои повеќе од две третини (74) се деца, вклучително и оние што се родени во Сирија и во Ирак барем од еден родител што е нивен државјанин. ${ }^{8}$ Кон крајот на декември 2019 година Босна и Херцеговина, исто

2 Исто.

3 Syrian Arab Republic: North East Syria: Al Hol Camp," ОСНА, 1 август 2019 год., https://reliefweb.int/sites/reliefweb.int/files/ resources/Al-Hol-Snapshot-SitRip-040819.pdf.

4 Keerthana Annamaneni, "For ISIS Children, Returning Home to Europe Meets Resistance," The New York Times, 15 aвryct 2019 год., https://www.nytimes.com/2019/08/15/world/europe/isis-children-belgium.html.

5 Комисија на Обединетите нации за истраги за Сирија, Escalating Violence and Waves of Displacement Continue to Torment Civilians during Eighth Year of Syrian Conflict (Женева: Совет за човекови права на Обединетите нации, 2019 год.), https://www.ohchr.org/EN/ HRBodies/HRC/Pages/NewsDetail.aspx?NewsID=24972\&LangID=E.

6 Исто.

7 Michael Birnbaum, "Months after the Fall of ISIS, Europe Has Done Little to Take Back Its Fighters," The Washington Post, 20 јуни 2019 год., https://www.washingtonpost.com/world/europe/after-caliphate-collapsed-europe-has-done-little-to-takeback- those-who-joined-isis/2019/06/20/4bab9cc2-8bc4-11e9-b6f4-033356502dce story.html.

8 Fatos Bytyci, "Kosovo Brings Back Fighters, Families of Jihadists from Syria," Reuters, 20 април 2019 год., https://www. reuters.com/article/us-kosovo-syria/kosovo-brings-back-fighters-families-of-jihadists-from-syria-idUSKCN1RW003. 
така, репатрираше 25 свои државјани, од кои 12 беа деца. ${ }^{9}$ Иако 25 репатрирани босански државјани се само една десетина од вкупниот број на босански државјани во камповите во Сирија - проценети на 260 лица според официјалните извори ${ }^{10}$ - нивната репатријација е од големо значење. Подготвеноста на Косово и на Босна, две инаку мали држави со скромни ресурси, да го олеснат враќањето на нивните државјани, особено деца, сигнализира дека може да се собере политичка волја за решавање на ова трнливо прашање на Западен Балкан, наспроти бројните објективни тешкотии.

Сепак, други земји во регионот главно покажуваат колебливост или немаат планови за примање назад на нивните државјани. Досега ниедна друга земја од Западен Балкан не објавила план или временска рамка за репатријација. Сѐ уште нема јасна стратегија за решавање на овој комплексен предизвик. Курдските импровизирани кампови и затвори нема да обезбедат долгорочно решение на ова актуелно прашање, особено имајќи предвид дека во контингентот на странски државјани што се држани таму преовладуваат ранливи малолетни лица што се подложени на тешкотии, кои лесно водат кон радикализација. ${ }^{11}$ Сегашната демографија на млади лица странски државјани поврзани со сирискиот конфликт бара проактивно дејствување, посебно размислување за возраста и полот и соодветни приспособувања на одговорите на политиките, во очекување на нивна репатријација. Ова е особено точно на Западен Балкан, кој има поголем број повратници или лица за кои постои веројатност да бидат репатрирани, а многу помалку од аспект на ресурсите, капацитетите и експертизата што се достапни за ефикасно справување со нив, во споредба со повеќето други европски држави.

\section{Препораки}

Новите истражувања и програми за повратниците од Сирија и од Ирак се само почеток во решавањето на предизвикот на малолетни повратници. Индивидуални усогласени програми „по мерка," при што ќе се внимава на возраста и на полот, се ретки. Иако искуството со ефективното ангажирање со деца повратници од Сирија и од Ирак е во своите рани фази, постепено се појавуваат првични добри практики од активностите за рехабилитација и реинтеграција. ${ }^{12}$ Корисните истражувања и добрите практики со работата на рехабилитација на деца војници или на малолетни лица изложени на траума поврзана со војната може да обезбедат информации за ефикасни политички одговори со цел решавање на прашањето на рехабилитација и реинтеграција на деца повратници на Западен Балкан, во согласност со водечките конвенции, договори и протоколи во кои се утврдени правата на децата.

\section{Проактивно, транспарентно и инклузивно креирање на политиките}

$\rightarrow$ Усвојување на проактивен и инклузивен мултиагенциски пристап, обврзувајќи се на долгорочна стратегија за рехабилитација и реинтеграција. Владините надлежни органи треба проактивно да инвестираат во мултиагециски партнерства и

9 "Authorities Say 25 Bosnians Sent Home from Camps in Syria," AP News, 19 декември 2019 год., https://apnews. com/850b5ffb b045c65f1dfbbce52c9ff182.

10 "Bosnia: Citizens Who Fought for IS in Syria Can Return," AP News, 11 ноември 2019 год., https://apnews.com/818776caf4a44 b6f97d8eb5c285ace00.

11 Совет за човекови права на Обединетите нации, Report of the Independent International Commission of Inquiry on the Syrian Arab Republic, A/HRC/42/51 (Њујорк: Генерално собрание на Обединетите нации, 2019 год.), https://www. securitycouncilreport.org/atf/cf/\%7B65BFCF9B-6D27-4E9C-8CD3-CF6E4FF96FF9\%7D/a hrc 42 51.pdf.

12 За повеќе информации, види: „Препорачана дополнителна литература, по теми“ на крајот од оваа Студија за политиките. 
програми што се флексибилни, соодветно финансирани и инклузивни, интегрирајќи го граѓанското општество во раните фази на процесот. Меѓународните донатори и специјализираните агенции треба да

обезбедат дополнително финансирање и активности за развој на капацитетите заради решавање на недостатокот на ресурси и експертиза. Со над 400 деца и 150 жени што до денес се репатрирани од Сирија и од Ирак ${ }^{13}$, активностите на Казахстан може да дадат согледувања во таквиот пристап. До крајот на 2019 година државата воспоставила 17 регионални центри за прифаќање и рехабилитација ${ }^{14}$, за сместување на повратниците на неограничен временски период, зависно од индивидуалните потреби и напредокот на дерадикализацијата. ${ }^{15}$ Центрите нудат не само услуги за сместување туку и лекарски и психолошки третман, образование, правна помош, арттерапија и оспособување за работа. ${ }^{16}$ Наставната програма е осмислена со учество на група НВО, додека социјални работници и владини агенции го координираат спроведувањето на програмата. ${ }^{17}$

$\rightarrow$ Со осмислувањето на протоколи приспособени за ангажирање на малолетни повратници тие треба да се објавуваат а процесот на имплементација да се децентрализира секогаш кога тоа е можно. Пристапот за ангажирање осмислен во врска со определени потреби на малолетните лица веројатно ќе поттикне поефикасно психосоцијално закрепнување и забрзана реинтеграција на децата повратници. Објавувањето на овие насоки би овозможило додадена транспарентност, отчетност и поддршка за процесот. Децентрализираниот пристап кон имплементацијата што ќе биде предводен од локалните надлежни органи и НВО веројатно ќе поттикне зголемена ангажираност и чувство на сопственост на процесот на рехабилитација и реинтеграција на ниво назаедницата. Наспротитоа што репатрирала само 17 малолетни лица ${ }^{18}$, главно сираци, на почетокот на 2020 година, Франција изработи и објави детални насоки и модалитети за третман на репатрираните малолетни француски и странски државјани што на почетокот на 2017 година се вратиле од Сирија и од Ирак. ${ }^{19}$ Стратегискиот документ ја нагласува водечката улога на локалните надлежни органи и на регионалните канцеларии и вклучува и план за координација и споделување информации меѓу агенциите што се одговорни за негова имплементација.

$\rightarrow$ Рамка и пристап за рехабилитација и реинтеграција на деца повратници преку образовниот објектив. Поради прашања на националната безбедност,

13 "Zhusan Operation: 595 Kazakhstanis Repatriated from Syria," Kazinform International News Agency, 6 февруари, 2020 год., https://www.inform.kz/en/zhusan-operation-595-kazakhstanis-repatriated-from-syria a3611674.

14 Stevan Weine "Rehabilitating the Islamic State's Women and Children Returnees in Kazakhstan," Јust Sесигіty, 12 декември, 2019 год., https://www.justsecurity.org/67694/rehabilitating-the-islamic-states-women-and-children-returnees-in-kazakhstan/. "39 Families Have Been Returned Back from Syria to Kazakhstan," Kazakhstan Today, 18 ноември 2019 год., https://www. kt.kz/ eng/international affair/39 families have been returned back from syria to kazakhstan 1153667282.html

Ksenia Bondal, "Kazakhstan Rehabilitating Children Recently Returned from Syria, Iraq," Caravanserai, 8 јануари, 2019 год., http:// central.asia-ews.com/en GB/articles/cnmi ca/features/2019/01/08/feature-01.

17 Andrew E. Kramer, "Kazakhstan Welcomes Women Back from the Islamic State, Warily," The New York Times, 10 август 2019 год., https://www.nytimes.com/2019/08/10/world/europe/kazakhstan-women-islamic-state-deradicalization.html.

18 Benjamin Sportouch $и$ Charles Deluermoz, “Enfants de jihadistes : 'Nous en avons rapatrié 17' en France, annonce Le Drian sur RTL," RTL, 2 февруари 2020 год., https://www.rtl.fr/actu/politique/ enfants-de-jihadistes-nous-en-avons-rapatrie-17-en-france-annonce-le-drian-sur-rtl-7800014980.

19 Кабинет на премиерот на Владата на Франција, Instruction relative à la prise en charge des mineurs à leur retour de zone irako-syrienne, Circular No. 5923/SG (Париз: Влада на Франција, март 2017 год.), http://circulaires.legifrance.gouv. fr/pdf/2017/03/cir 41965.pdf. 
некои аспекти на репатријацијата и на рехабилитацијата и реинтеграцијата на повратниците, особено на возрасните, неизбежно се поврзани со спроведувањето на законот и со кривичното правосудство. Меѓутоа, за децата, образованието и стручното усовршување се некои од најважните аспекти на рехабилитацијата и реинтеграцијата, нудејќи пат кон нова иднина, како во програмите за реинтеграција на деца војници. ${ }^{20}$ Со оглед на ова, министерството за образование во секоја држава од Западен Балкан, на пример, може да биде во подобра позиција и посоодветно од министерството за внатрешни работи кога станува збор за водење и координирање на рехабилитацијата на деца вклучени во насилен екстремистички конфликт. Изборот на министерството е важен затоа што го одразува и й го соопштува на јавноста севкупниот начин на размислување на владата околу ангажираноста. Владата на Казахстан одлучи за програмата за рехабилитација и реинтеграција да го задолжи Министерството за образование. Нивното искуство може да даде корисни согледувања во тој однос. ${ }^{21}$

\section{Заштита и поддршка на детето}

$\rightarrow$ Мерки за поддршка што ги утврдуваат приоритетите во најдобар интерес на децата повратници и нивна најбрза можна рехабилитација и реинтеграција во главните текови на општеството. Правосудните институции треба да дејствуваат во согласност со меѓународното право и применливите стандарди за малолетничко правосудство. Во случаи кога се бара прогонување на деца помлади од 18 години, треба да се разгледаат алтернативи за притворот пред судење и за затворањето, во согласност со Конвенцијата за правата на детето. ${ }^{22}$ Резолуцијата 70/291 на Генералното собрание за Ревизија на глобалната Стратегија на Обединетите нации за контратероризам, се однесува на ова конкретно прашање и треба да се консултира при изработка на соодветните правни механизми. ${ }^{23}$

$\rightarrow$ Проценанаризицитеинапотребитезарадиоценувањенаменталнатаблагосостојба и на нивото на траума кај деца повратници пред давање психосоцијална поддршка приспособена на индивидуалните потреби. Децата повратници биле изложени на акти на екстремно насилство и во некои случаи можеби лично доживеале екстремно насилство. Во други случаи, тие можеби учествувале во извршување на насилни екстремистички акти. Агенциите што се задолжени за јавно здравје треба да спроведуваат детални и периодични процени за да го оценат секој случај одделно. ${ }^{24}$ Со оглед на тоа што некои постари деца меѓу повратниците веројатно

20 Канцеларија на специјалниот претставник на генералниот секретар за деца и вооружен конфликт, Reintegration of Former Child Soldiers (Њујорк: Секретаријат на Обединетите нации, 2018 год.), https://childrenandarmedconflict.un.org/ wp-content/uploads/2018/09/Reintergration-brochure-layout.pdf; Skënder Perteshi и Ramadan Ilazi, Unpacking Kosovo's Response to Returnees from the War Zones in Syria and Iraq (Приштина: Косовски центар за безбедносни студии, 2020 год.), http://www.qkss.org/repository/docs/violent-extremism-eng 978757.pdf.

21 Weine, "Rehabilitating the Islamic State's Women and Children Returnees in Kazakhstan."

22 Convention on the Rights of the Child (Њујорк: Генерално собрание на Обединетите нации, 1989 год.), https://www.ohchr. org/en/profes- sionalinterest/pages/crc.aspx; Канцеларија на Обединетите нации за борба против тероризмот (UNCCT), Children Affected by the Foreign-fighter Phenomenon: Ensuring a Child Rights-based Approach (Њујорк: UNCCT, 2019 год.), https://www.un.org/counterterrorism/ctitf/sites/www.un.org.counterterrorism.ctitf/files/ftf handbook web reduced.pdf.

23 Генерално собрание на Обединетите нации, 70. сесија, "Resolution 70/291 [The United Nations Global Counter-Terrorism Strategy Review]” (A/RES/70/291) 1 јули 2016 год., https://www.un.org/sc/ctc/news/ document/a-res-70-291-the-united-nations-global-counter-terrorism-strategy-review/.

24 Организација за безбедност и соработка во Европа (ОБСЕ), Non-custodial Rehabilitation and Reintegration in Preventing and Countering Violent Extremism and Radicalization That Lead to Terrorism A Guidebook for Policymakers and Practitioners 
биле подложени на насилна екстремистичка индоктринација и обука додека биле во Сирија и во Ирак, надлежните органи треба да го проценат нивниот потенцијален ризик и да обезбедат специјализирана грижа за да се зафатат со решавање на нивната индоктринација и обука пред да ги префрлат во средината на јавното образование. Кон крајот на април 2019 година Косово репатрирало 74 малолетници од Сирија. Во септември, сите деца на училишна возраст меѓу повратниците биле

подготвени дапочнат соучилиште. ${ }^{25}$ Со оглед натоа што нивното ефикасно вклучување во главните текови на општеството е крајна цел на процесот на реинтеграција, запишувањето на децата повратници во училиште е позитивен чекор. Сепак, не е јасно колкава индивидуално приспособена психолошка и академска поддршка тие добиле пред да се запишат во јавно училиште неколку месеци по нивното враќање.

$\rightarrow$ Спроведување психометриски тестови за да се оцени интелектуалниот развој на децата повратници со цел да се обезбеди нивно точно позиционирање во образовниот систем и ако е потребно, академска помош. Овие активности веројатно ќе бидат поефикасни ако децата не се институционализирани туку добиваат академска обука и психолошка помош дома, можеби од мобилни тимови експерти. Ова може да помогне да се избегнат чувства на неадекватност, стигма и потенцијална маргинализација додека повратниците не почнат да се чувствуваат попријатно во новата социјална средина. На пример, во Франција, откако обвинителот и судијата за малолетници ќе го оценат случајот на секое дете повратник, малолетните лица се подложени на соматско и психолошко испитување подзаштита на социјалнитеслужби. Одлуките за школувањето се носат во консултација меѓу академскиот директор на националните образовни служби, образовните институции и практичарите што ги спроведуваат и следат активностите за рехабилитација и реинтеграција. ${ }^{26}$

\section{Заклучок}

Успешната рехабилитација и реинтеграција на децата повратници на крај ќе наложи донесување на стратегија за холистичка психосоцијална поддршка, што ќе се зафати со сите аспекти на нивната социјална интеракција и реинтеграција дома, на училиште и во заедницата. Така, напредокот на секое дете повратник во насока на рехабилитација и реинтеграција ќе биде во огромна мера под влијание на гледиштата и ставовите на родителите и роднините што живеат со него. Значи, програмите треба да понудат поширока поддршка за да се решат прашањата на радикализација кон насилство и на траума во рамките на целото семејство. Исто така, наставниците и другите практичари вклучени во образованието и во процесот на рехабилитација на децата бегалци треба да добијат обука за зголемување на свеста за трауми и информации за процесот на радикализација, вклучително и за тоа како да одговорат на знаци поврзани со однесувањето и каде да бараат дополнителна поддршка. Со подобрени знаења, вештини и алатки за решавање на загриженоста на заедниците што ги примаат повратниците и реалноста на искуствата на повратниците, државите од Западен Балкан може да помогнат за полесно и побезбедно вклучување на повратниците во главните текови на општеството.

in South-Eastern Europe (Виена, ОБСЕ, 2020 год.), https://www.osce.org/secretariat/444838?download=true.

25 Taulant Qenaj, "Fëmijët e Kthyer Nga Siria, Sërish Në Shkolla," Radio Evropa e Lirë, 27 август, 2019 год., https://www. evropaelire. org/a/femijet-e-kthyer-nga-siria-shkollim-/30130050.html.

26 Кабинет на премиерот на Владата на Франција, Instruction relative à la prise en charge des mineurs à leur retour de zone irako-syrienne, Circular No. 5923/SG.

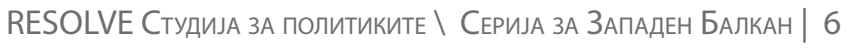




\section{Предложена дополнителна литература, по}

\section{теми}

\section{За регрутирањето и користењето на деца од терористи}

Bloom, Mia, with John Horgan. Small Arms: Children and Terrorism. Ithaca, New York: Cornell University Press, 2019.

Канцеларија на Обединетите нации за дрога и криминал (UNODC). Handbook on Children Recruited and Exploited by Terrorist and Violent Extremist Groups: The Role of the Justice System. Виена: UNODC, 2017 год. https://www.unodc.org/documents/justice-and-prison-reform/Child-Victims/ Handbook on Children Recruited_and Exploited by Terrorist and Violent Extremist Groups the Role of the Justice System.E.pdf.

\section{За децата поврзани со терористички организации во Сирија и во Ирак}

Cook, Joana u Gina Valle. "From Daesh to 'Diaspora' II: The Challenges Posed by Women and Minors After the Fall of the Caliphate." СтC Sentinel 12, no. 6 (јули 2019 год.): 30-45. (јули 2019) https://ctc. usma. edu/daesh-diaspora-challenges-posed-women-minors-fall-caliphate/.

\section{За рехабилитацијата и реинтеграцијата на децата}

Meines, Marije, Merel Molenkamp, Omar Ramadan и Magnus Ranstorp. RAN Manual: Responses to Returnees: Foreign Terrorist Fighters and their Families. Амстердам: Центар за извонредност на Мрежата за зголемување на свеста за радикализацијата (RAN), 2017 год. https://ec.europa. eu/home-affairs/sites/homeaffairs/files/ ran br a4 m10 en.pdf.

Глобален форум за контратероризам (GCTF). Good Practices on Addressing the Challenge of Returning Families of Foreign Terrorist Fighters. GCTF, 2018 год. https://www.thegctf.org/Portals/1/Documents/Framework\%20Documents/2018/GCTF-Good-Practices-on-Returning-Families-of-FTFs ENG. pdf?ver=2018-09-25-101427-323.

Обединети нации. Кеy Principles for the Protection, Repatriation, Prosecution, Rehabilitation and Reintegration of Women and Children with Links to United Nations Listed Terrorist Groups. Обединети нации, 2019 год. https://www.un.org/counterterrorism/ctitf/sites/www.un.org. counterterrorism.ctitf/files/Key\%20 Principles\%20-\%20April\%202019 0.pdf.

Канцеларија на Обединетите нации за борба против тероризмот (UNCCT). Children Affected by the Foreign-fighter Phenomenon: Ensuring a Child Rights-based Approach. Њујорк: UNCCT, 2019 год. https://www.un.org/counter- terrorism/ctitf/sites/www.un.org.counterterrorism.ctitf/files/ftf handbook web reduced.pdf

Канцеларија на Обединетите нации за дрога и криминал (UNODC). Roadmap on the Treatment of Children Associated with Terrorist and Violent Extremist Groups. Виена: UNODC, 2019 год. https:// indd.adobe.com/ view/61793921-8dc6-4fc2-9e46-b27c6390fff2.

van der Heide, Liesbeth $\mathrm{n}$ Jip Geenen. Children of the Caliphate: Young IS Returnees and the Reintegration Challenge. Хаг: Меѓународен центар за борба против тероризмот - Хаг, 2017 год. https://icct. nl/wp-content/uploads/2017/08/ICCT-vanderHeide-Geenen-Children-of-the-Caliphate-2.pdf.

За предизвиците со кои се соочуваат практичарите што работат со деца повратници

Мрежа за зголемување на свеста за радикализацијата (RAN). Child Returnees from Conflict Zones. Амстердам: Центар за извонредност на RAN, 2016 год. https://ec.europa.eu/home-affairs/ 
sites/homeaffairs/files/what-we-do/networks/radicalisation awareness network/ran-papers/ docs/issue paper child returnees from conflict zones 112016 en.pdf.

\section{Извори}

"39 Families Have Been Returned Back from Syria to Kazakhstan." Kazakhstan Today, 18 ноември 2019 год. https://www.kt.kz/ eng/ international affair/39 families have been returned back from syria to kazakhstan 1153667282.html.

Annamaneni, Keerthana. "For ISIS Children, Returning Home to Europe Meets Resistance." The New York Times, 15 aвгуст 2019 год. https://www.nytimes.com/2019/08/15/world/europe/isis-children-belgium.html.

"Authorities Say 25 Bosnians Sent Home from Camps in Syria." АP News, 19 декември 2019 год. https://apnews.com/850b5ffbb045 c65f1dfbbce52c9ff182.

Birnbaum, Michael. "Months after the Fall of ISIS, Europe Has Done Little to Take Back Its Fighters." The Washington Post, 20 jyни 2019 год. https://www.washingtonpost.com/world/europe/after-caliphate-collapsed-europe-has-done-little-to-take-backthose-who-joined-isis/2019/06/20/4bab9cc2-8bc4-11e9-b6f4-033356502dce story.html.

Bondal, Ksenia. "Kazakhstan Rehabilitating Children Recently Returned from Syria, Iraq." Caravanserai, 8 јануари 2019 год. httр:// central.asia-ews.com/en GB/articles/cnmi ca/features/2019/01/08/feature-01.

"Bosnia: Citizens Who Fought for IS in Syria Can Return." AP News, 11 ноември 2019 год. https://apnews.com/818776caf4a44b6f $\underline{97 d 8 e b 5 c 285 a c e 00 .}$

Bytyci, Fatos. "Kosovo Brings Back Fighters, Families of Jihadists from Syria." Reuters, 20 април 2019 год. https://www.reuters. com/article/us-kosovo-syria/kosovo-brings-back-fighters-families-of-jihadists-from-syria-idUSKCN1RW003.

Kramer, Andrew E. "Kazakhstan Welcomes Women Back from the Islamic State, Warily." The New York Times, 10 август 2019 год. https://www.nytimes.com/2019/08/10/world/europe/kazakhstan-women-islamic-state-deradicalization.html.

Канцеларија на специјалниот претставник на генералниот секретар за деца и вооружен конфликт. Reintegration of Former Child Soldiers. Њујорк: Секретаријат на Обединетите нации, 2018 год. https://childrenandarmedconflict.un.org/ $\underline{\text { wp-content/uploads/2018/09/ Reintergration-brochure-layout.pdf. }}$

Организација за безбедност и соработка во Европа (ОБСЕ). Non-custodial Rehabilitation and Reintegration in Preventing and Countering Violent Extremism and Radicalization That Lead to Terrorism A Guidebook for Policymakers and Practitioners in South-Eastern Europe. Виена, ОБСЕ, 2020 год. https://www.osce.org/secretariat/444838?download=true.

Perteshi, Skënder и Ramadan Ilazi. Unpacking Kosovo's Response to Returnees from the War Zones in Syria and Iraq. Приштина: Косовски центар за безбедносни студии, 2020 год. http://www.qkss.org/repository/docs/violent-extremism-eng 978757.pdf.

Кабинет на премиерот на Владата на Франција. Instruction relative à la prise en charge des mineurs à leur retour de zone irako-syrienne, Circular No. 5923/SG. Париз: Влада на Франција, март 2017 год. http://circulaires.legifrance.gouv.fr/ pdf/2017/03/cir 41965.pdf.

Qenaj, Taulant. "Fëmijët e Kthyer Nga Siria, Sërish Në Shkolla." Radio Evropa e Lirë, 27 август 2019 год. https://www.evropaelire. org/a/femijet-e-kthyer-nga-siria-shkollim-/30130050.html.

Shtuni, Adrian. "Western Balkans Foreign Fighters and Homegrown Jihadis: Trends and Implications, Combating Terrorism." СТC Sentinel 12, no. 7 (13 август 2019 год.):18-24. https://ctc.usma.edu/ western-balkans-foreign-fighters-homegrown-jihadis- trends-implications/.

Sportouch, Benjamin и Charles Deluermoz. "Enfants de jihadistes: 'Nous en avons rapatrié 17' en France, annonce Le Drian sur RTL." RTL, 2 февруари 2020 год. https://www.rtl.fr/actu/politique/enfants-de-jihadistes-nous-en-avons-rapatrie-17-enfrance- annonce-le-drian-sur-rtl-7800014980. 
"Syrian Arab Republic: North East Syria: Al Hol Camp." ОСНА, 1 август 2019 год. https://reliefweb.int/sites/reliefweb.int/files/ resources/Al-Hol-Snapshot-SitRip-040819.pdf.

Комисија на Обединетите нации за истрага за Сирија. Escalating Violence and Waves of Displacement Continue to Torment Civilians during Eighth Year of Syrian Conflict. Женева: Совет за човекови права на Обединетите нации, 2019 год. https:// www.ohchr.org/EN/HRBodies/ HRC/Pages/NewsDetail.aspx?NewsID=24972\&LangID=E.

Генерално собрание на Обединетите нации. Convention on the Rights of the Child. Њујорк: Генерално собрание на Обединетите нации, 1989 год. https://www.ohchr.org/en/professionalinterest/pages/crc.aspx.

-—-,70.сесија. "Resolution70/291[TheUnited Nations GlobalCounter-TerrorismStrategyReview]”(A/RES/70/291)1јули2016год. https://www.un.org/sc/ctc/news/document/a-res-70-291-the-united-nations-global-counter-terrorism-strategy-review/.

Совет за човекови права на Обединетите нации. Report of the Independent International Commission of Inquiry on the Syrian Arab Republic, A/ HRC/42/51. Њујорк: Генерално собрание на Обединетите нации, 2019 год. https://www. securitycouncilreport.org/atf/cf/\%7B65BFCF9B- 6D27-4E9C-8CD3-CF6E4FF96FF9\%7D/a hrc 42 51.pdf.

Канцеларија на Обединетите нации за борба против тероризмот (UNCCT). Children Affected by the Foreign-fighter Phenomenon: Ensuring a Child Rights-based Approach. Њујорк: UNCCT, 2019 год. https://www.un.org/counterterrorism/ctitf/sites/www. $\underline{\text { un.org.counterterrorism.ctitf/files/ftf handbook web reduced.pdf. }}$

Weine, Stevan. "Rehabilitating the Islamic State's Women and Children Returnees in Kazakhstan." Just Security, 12 декември 2019 год. https://www.justsecurity.org/67694/rehabilitating-the-islamic-states-women-and-children-returnees-in-kazakhstan/.

"Zhusan Operation: 595 Kazakhstanis Repatriated from Syria." Kazinform International News Agency, 6 февруари 2020 год. httрs:// www.inform.kz/en/zhusan-operation-595-kazakhstanis-repatriated-from-syria a3611674. 


\section{3a Cmydujama}

Автор: Адриан Штуни, генерален директор на Штуни Консалтинг лЛЦ, е специјалист за надворешна политика, безбедност и за стратегиски комуникации со регионален фокус на Западен Балкан. Тој ги консултира владините агенции на САД, академските институции и меѓународните организации во Соединетите Американски Држави, Европа и во Азија за спротивставување на насилен екстремизам, контратероризам, политички ризици, спротивставување на надворешна пропаганда и дезинформации и за други транснационални закани.

Ставовите искажани во оваа публикација се ставови на авторите. Тие нужно не ги одразуваат ставовите на RESOLVE Network, Американскиот Институт за мир или на кој било субјект во владата на САД.

RESOLVE NETWORK

подобрени истражувања॰практика заснована на информации॰унапредена политика за насилниот екстремизам. WWW.resolvenet.org (9) in 